\title{
Identification of Bacteria and Fungi Contamination of Some Classrooms at Srinakharinwirot University, Ongkharak Campus
}

\author{
Pattakorn Buppan ${ }^{1, *}$, Apisara Sommatas ${ }^{1}$, Pareena Nakprasom ${ }^{1}$, Natawan Noicharoen ${ }^{1}$ \\ and Dollaya Sangsuvan ${ }^{1}$ \\ ${ }^{1}$ Department of Health Promotion, Faculty of Physical Therapy, Srinakharinwirot University, Thailand \\ ${ }^{*}$ Corresponding Author's Email: Pattakorn.b [AT] gmail.com
}

\begin{abstract}
The air quality of air inside the classroom is an important factor effect to health of people. The objective of the study was to estimation the air quality and identification of bacteria and fungi contamination in the air inside the classroom at Srinakharinwirot University Ongkharak Campus. The open plate technique was used to collect samples in the morning at 8.30 a.m. (before students enter to the classroom) and in the afternoon at 4.30 p.m. (after students left the classroom) between November 2018 to April 2019. The result showed that the average amounts of bacteria and fungi were 67.60 to 352.50 and 69.60 to $370.80 \mathrm{CFU} / \mathrm{dm}^{2} / \mathrm{h}$, respectively. The evaluations of the index of microbial air contamination (IMA) were fair to very poor. However, the concentrations of airborne bacteria and fungi were not higher than the proposed air quality index. Therefore, the air quality of classrooms had a good hygienic standard. The most isolated bacteria were Enterobacter spp., Escherichia coli, Staphylococcus spp., Bacillus spp., and Pseudomonas spp. and fungi were found to include Cladosporium spp., Aspergillus spp., Penicillium citrinum and Neurospora crassa. So, the air quality of air inside classroom control management is appropriate to be used to reduce bacteria and fungi contamination in the classroom.
\end{abstract}

Keywords - microorganism in the air, indoor air quality, classroom, contamination

\section{INTRODUCTION}

Indoor air quality is an important factor affect the health of people concern as most people spend more than $90 \%$ of their life indoors, in houses, offices buildings and classrooms [1, 2]. Indoor air pollution is associated with inadequate building environments, including building materials, air conditioning systems, ventilation rates, and human factors, such as overcrowding in constrained spaces $[3,4,5]$.

One of the factors to the effect of indoor air quality is the contamination of microorganism which includes bacteria, fungi and viruses. Moreover, A high concentration of microorganisms in the air can be the allergenic disease. The most isolated airborne bacteria and fungi found the contamination in laboratory rooms, libraries, hospitals and schools such as Staphylococcus spp., Microcccus spp., Bacillus spp., Serratia spp., Penicillium spp., Aspergillus spp., Rhizopus spp., Cladosporium spp., Fusarium spp. and Curvularia spp. which these microorganisms associate with allergy and asthma $[6,7,8,9]$.

The objective of the study was to estimation the air quality and identification of bacteria and fungi contamination in the air inside the classroom at Srinakharinwirot University, Ongkharak Campus.

\section{METHODOLOGY}

\section{Sample Collections}

Airborne bacteria and fungi were taken in the classroom at Srinakharinwirot University Ongkharak Campus. This study included a total of five hundred three seventy samples of 38 classrooms were collected including 5 faculty using the open plate technique. In this technique, standard $90 \mathrm{~mm}$ diameter Petri dishes containing $20 \mathrm{ml}$. of plate count agar (PCA) and Potato dextrose agar (PDA) to collect bacteria and fungi, respectively. The both plate were left open to air and placed at two positions in each classroom. The sampling height was $1 \mathrm{~m}$ above the floor and $1 \mathrm{~m}$ away from the wall for $60 \mathrm{~min}$. The samples were collected twice a day at in the morning at $8.30 \mathrm{a} . \mathrm{m}$. (before students enter to the classroom) and in the afternoon at 4.30 p.m. (after students left the classroom) between November 2018 to April 2019. After exposure, the sample was taken to the laboratory (Department of Health Promotion, Faculty of Physical Therapy, Srinakharinwirot University). 


\section{Microbiological Assessed}

The samples were incubated at $37^{\circ} \mathrm{C}$ at $48 \mathrm{~h}$ for bacteria and at $25^{\circ} \mathrm{C}$ at 5 to 7 days for fungi. The amount of bacteria and fungi colonies were counted and calculated the number of colony forming unit (CFU)/plate/h. and calculated the number of $\mathrm{CFU} / \mathrm{dm}^{2} / \mathrm{h}$ to compare with the index of microbial air contamination classes (IMA class) [11] (Table 1).

Table 1: The index of microbial air contamination

\begin{tabular}{ccc}
\hline \hline IMA value & CFU/dm $/ \mathrm{h}$ & Class \\
\hline $0-5$ & $0-9$ & very good \\
$6-25$ & $10-39$ & good \\
$26-50$ & $40-84$ & fair \\
$51-75$ & $85-124$ & poor \\
$\geq 76$ & $\geq 125$ & very poor \\
\hline \hline
\end{tabular}

\section{Isolation and identification}

Bacterial isolates were characterized and identified using cultural, morphological and microscopic examinations. Different biochemical tests such as Gram staining, Catalase, Coagulase, DNase, Methyl-red, Oxidase, Voges-proskauer and sugar fermentation test were employed to differentiate the bacterial isolates [12].

Fungi colonies were identified using standard microbiological procedures based on their colony appearance, microscopic examination of their spores and hypal characteristics using lactophenol cotton blue preparation [13].

\section{Statistical analysis} necessary.

Simple percentage was used to express the frequency of occurrence of bacterial and fungi isolates where

\section{RESULTS AND DISCUSSION}

The average amounts of airborne bacteria and fungi were 67.6-352.5 CFU/dm $2 / \mathrm{h}$ (Table 2) and 69.6-370.8 $\mathrm{CFU} / \mathrm{dm}^{2} / \mathrm{h}$ (Table 3), respectively. The evaluations of the Index of IMA of airborne bacteria and fungi in all laboratories were fair to very poor. Those concentrations of airborne bacteria and fungi compare with air quality index of Malaysia [14] were not exceed $500 \mathrm{CFU} / \mathrm{m}^{3}$ for bacteria and $1000 \mathrm{CFU} / \mathrm{m}^{3}$ for fungi which as the good quality air. The comparison of the number of airborne bacteria and fungi in during time and between the faculty was no statistically significant difference $(p>0.05)$ (Table 2 and 3$)$.

Table 2: Amount of airborne bacteria of classroom at Srinakharinwirot University, Ongkharak Campus.

\begin{tabular}{|c|c|c|c|c|c|c|c|}
\hline \multicolumn{8}{|c|}{ Airborne bacteria } \\
\hline $\begin{array}{l}\text { Investigated } \\
\text { room }\end{array}$ & $\begin{array}{l}\text { Sampling } \\
\text { time }\end{array}$ & $\begin{array}{c}\text { Mean } \\
\text { (colony) }\end{array}$ & $\mathrm{CFU} / \mathrm{dm}^{2} / \mathrm{h}$ & IMA & $\begin{array}{l}\text { Air quality } \\
\text { index } \\
(\geq 500 \\
\left.\text { CFU/m } \text { m }^{3}\right)^{*}\end{array}$ & $\begin{array}{l}\text { During } \\
\text { time } \\
\text { (p-value) }\end{array}$ & $\begin{array}{c}\text { Between faculty } \\
\text { (p-value) }\end{array}$ \\
\hline \multirow{2}{*}{ PT } & 8.30 a.m. & 57.70 & 90.70 & poor & Pass & \multirow{2}{*}{0.667} & 0.29 \\
\hline & 4.30 p.m. & 43.30 & 68.00 & fair & Pass & & 0.217 \\
\hline \multirow{2}{*}{ NS } & 8.30 a.m. & 171.30 & 340.50 & $\begin{array}{l}\text { vary } \\
\text { poor }\end{array}$ & Pass & \multirow{2}{*}{0.499} & 0.29 \\
\hline & 4.30 p.m. & 180.90 & 194.40 & $\begin{array}{l}\text { vary } \\
\text { poor }\end{array}$ & Pass & & 0.217 \\
\hline \multirow{2}{*}{$\mathrm{PE}$} & 8.30 a.m. & 43.10 & 67.60 & fair & Pass & \multirow{2}{*}{0.655} & 0.29 \\
\hline & 4.30 p.m. & 73.30 & 114.70 & poor & Pass & & 0.217 \\
\hline \multirow{2}{*}{ EN } & 8.30 a.m. & 175.70 & 276.10 & $\begin{array}{l}\text { vary } \\
\text { poor }\end{array}$ & Pass & \multirow{2}{*}{0.926} & 0.29 \\
\hline & 4.30 p.m. & 184.30 & 289.60 & $\begin{array}{l}\text { vary } \\
\text { poor }\end{array}$ & Pass & & 0.217 \\
\hline \multirow{2}{*}{$\mathrm{LT}$} & 8.30 a.m. & 216.70 & 352.50 & $\begin{array}{l}\text { vary } \\
\text { poor }\end{array}$ & Pass & \multirow{2}{*}{0.499} & 0.29 \\
\hline & 4.30 p.m. & 123.70 & 194.40 & $\begin{array}{l}\text { vary } \\
\text { poor }\end{array}$ & Pass & & 0.217 \\
\hline
\end{tabular}

*air pollution index of Malaysia (industry code of practice on indoor air quality 2010) 
Table 3: Amount of airborne fungi of classroom at Srinakharinwirot University, Ongkharak Campus.

\begin{tabular}{|c|c|c|c|c|c|c|c|}
\hline \multicolumn{8}{|c|}{ Airborne fungi } \\
\hline $\begin{array}{l}\text { Sampling } \\
\text { locations }\end{array}$ & $\begin{array}{l}\text { Sampling } \\
\text { time }\end{array}$ & $\begin{array}{c}\text { Mean } \\
\text { (colony) }\end{array}$ & $\mathrm{CFU} / \mathrm{dm}^{2} / \mathrm{h}$ & IMA & $\begin{array}{l}\text { Air quality } \\
\text { index } \\
(\geq 1000 \\
\left.\text { CFU/m })^{3}\right)^{*}\end{array}$ & $\begin{array}{c}\text { During } \\
\text { time } \\
\text { (p-value) }\end{array}$ & $\begin{array}{c}\text { Between faculty } \\
\text { (p-value) }\end{array}$ \\
\hline \multirow{2}{*}{ PT } & 8.30 a.m. & 236.0 & 370.80 & vary poor & Pass & \multirow{2}{*}{0.232} & 0.721 \\
\hline & 4.30 p.m. & 44.30 & 69.60 & fair & Pass & & 0.410 \\
\hline \multirow{2}{*}{ NS } & 8.30 a.m. & 151.30 & 238.40 & vary poor & Pass & \multirow{2}{*}{0.635} & 0.721 \\
\hline & 4.30 p.m. & 118.30 & 185.90 & vary poor & Pass & & 0.410 \\
\hline \multirow{2}{*}{ PE } & 8.30 a.m. & 179.00 & 281.30 & vary poor & Pass & \multirow{2}{*}{0.121} & 0.721 \\
\hline & 4.30 p.m. & 62.30 & 97.90 & poor & Pass & & 0.410 \\
\hline \multirow{2}{*}{ EN } & 8.30 a.m. & 125.70 & 197.50 & vary poor & Pass & \multirow{2}{*}{0.377} & 0.721 \\
\hline & 4.30 p.m. & 60.30 & 94.80 & poor & Pass & & 0.410 \\
\hline \multirow{2}{*}{ LT } & 8.30 a.m. & 210.70 & 340.50 & vary poor & Pass & \multirow{2}{*}{0.499} & 0.721 \\
\hline & 4.30 p.m. & 123.70 & 194.40 & vary poor & Pass & & 0.410 \\
\hline
\end{tabular}

*air pollution index of Malaysia (industry code of practice on indoor air quality 2010)

Attempts were performed to identify the bacteria from the colonies more often isolated from sampling sites in the third seasons are represented on Table 4. Over four five hundred and seventy-six isolated colonies were selected at random and biochemically characterized to establish an overall taxonomic classification of the airborne bacteria at the level of genus. The most isolated bacteria were Enterobacter spp., Escherichia coli, Staphylococcus spp., Bacillus spp., and Pseudomonas spp. to a lesser extent to Stenotrophomonas spp., Proteus penneri, Acinetobacter spp. and Micrococcus spp. Enterobacter was also occasionally isolated as a representative member of the enterobacteriaceae family. The above results reveal that the bacteria most often isolated are gram-positive cocci belonging to saprophytic microflora generally associated to human skin and mucosa, thereby suggesting that the main bacterial contamination suspended into the indoor air derives from human presence.

The frequency of fungi species isolated from the sampled classroom. The most isolated of the fungal is as follows; Cladosporium spp., Aspergillus spp., Penicillium citrinum and Neurospora crassa. to a lesser extent to Aspergillus flavus, Aspergillus niger, Candida albicans, Curvularia shahidchamranensis, Curvularia lunata, Fusarium spp., Penicillium citrinum, Penicillium roqueforti, Penicillium spp. and Rhizopus spp. As shown in Table 4, Cladosporium spp. (17.65\%), Aspergillus spp. (16.10\%), Penicillium citrinum (13.10\%) and Neurospora crassa. (12.07\%) were the most abundant fungi genera in the third seasons.

The concentrations of airborne bacteria and fungi in the contamination in the air inside classroom at Srinakharinwirot University Ongkharak campus. were not higher than proposed air quality index $\left(\geq 500 \mathrm{CFU} / \mathrm{m}^{3}\right.$ for bacteria and $\geq 1000 \mathrm{CFU} / \mathrm{m}^{3}$ for fungi) [14]. The result showed that all classrooms had good hygienic standard. Moreover, the amount of airborne bacteria and fungi were not depending on the period of time and type of classrooms. The microbial isolates included three bacteria (Micrococcus spp., Gram negative bacilli (non-pathogenic bacteria) and Bacillus spp.) [1,15] and four fungi (Penicillium spp., Curvularia spp., Rhizopus spp. and Cladosporium spp.) [16]. The data were according to several reports that demonstrated these microbial were isolated in laboratory and indoor environment. The most isolated bacteria were Enterobacter spp. that was also occasionally isolated as a representative member of the enterobacteriaceae family. The Cladosporium spp. and Aspergillus spp. were recognized as opportunistic pathogens for humans and often associated with allergy and asthma [17, 18]. 
Table 4: Observation frequency of bioaerosols (\%).

\begin{tabular}{|c|c|c|c|c|c|c|c|c|}
\hline \multirow{2}{*}{ Bacteria specie/genus } & \multicolumn{2}{|c|}{ Rainy season } & \multicolumn{2}{|c|}{ Cool season } & \multicolumn{2}{|c|}{ Hot season } & \multirow{2}{*}{ Total } & \multirow{2}{*}{ Frequency $(\%)$} \\
\hline & 8.30 a.m. & 4.30 p.m. & 8.30 a.m. & 4.30 p.m. & 8.30 a.m. & 4.30 p.m. & & \\
\hline 1.Enterobacter spp. & 43 & 22 & 17 & 8 & 13 & 8 & 111 & 19.27 \\
\hline 2.Escherichia coli & 35 & 24 & 12 & 8 & 8 & 6 & 93 & 16.15 \\
\hline 3.Staphylococcus spp. & 28 & 17 & 12 & 6 & 18 & 8 & 89 & 15.45 \\
\hline 4.Bacillus spp. & 22 & 13 & 18 & 12 & 10 & 4 & 79 & 13.72 \\
\hline 5.Pseudomonas spp. & 17 & 15 & 9 & 6 & 17 & 9 & 73 & 12.67 \\
\hline 6.Stenotrophomonas spp. & 7 & 4 & 12 & 19 & 1 & 1 & 44 & 7.64 \\
\hline 7.Proteus penneri & 6 & 6 & 8 & 15 & 2 & 1 & 38 & 6.60 \\
\hline 8.Acinetobacter spp. & 7 & 4 & 3 & 2 & 5 & 6 & 27 & 4.69 \\
\hline 9.Micrococcus spp. & 6 & 4 & 4 & 5 & 2 & 1 & 22 & 3.82 \\
\hline \multirow{2}{*}{ Fungi specie/genus } & \multicolumn{2}{|c|}{ Rainy season } & \multicolumn{2}{|c|}{ Cool season } & \multicolumn{2}{|c|}{ Hot season } & \multirow{2}{*}{ Total } & \multirow{2}{*}{ Frequency (\%) } \\
\hline & 8.30 a.m. & 4.30 p.m. & 8.30 a.m. & 4.30 p.m. & 8.30 a.m. & 4.30 p.m. & & \\
\hline 1.Aspergillus spp. & 9 & 3 & 6 & 7 & 19 & 8 & 52 & 16.10 \\
\hline 2.Aspergillus flavus & 4 & 1 & 2 & 2 & 13 & 4 & 26 & 8.05 \\
\hline 3.Aspergillus niger & 2 & 5 & 9 & 4 & 2 & - & 22 & 6.81 \\
\hline 4.Candida albicans & 1 & 2 & 2 & 3 & 2 & 1 & 11 & 3.41 \\
\hline 5.Cladosporium spp. & 4 & 2 & 18 & 13 & 13 & 7 & 57 & 17.65 \\
\hline $\begin{array}{l}\text { 6.Curvularia } \\
\text { shahidchamranensis }\end{array}$ & 2 & 2 & 6 & 4 & 2 & 2 & 18 & 5.57 \\
\hline 7.Curvularia lunata & 2 & 2 & 3 & 1 & 7 & 2 & 17 & 5.26 \\
\hline 8.Fusarium spp. & 2 & 1 & 1 & 3 & 6 & 4 & 17 & 5.26 \\
\hline 9.Neurospora crassa & 3 & 4 & 9 & 6 & 8 & 9 & 39 & 12.07 \\
\hline 10.Penicillium citrinum & 3 & 1 & 8 & 5 & 16 & 9 & 42 & 13.00 \\
\hline 11.Penicillium roqueforti & 2 & 1 & 4 & 2 & 7 & 5 & 21 & 6.50 \\
\hline 12.Penicillium spp. & 3 & 1 & 3 & 1 & 1 & 5 & 14 & 4.33 \\
\hline 13.Rhizopus spp. & 4 & 2 & 1 & 1 & 5 & - & 13 & 4.02 \\
\hline
\end{tabular}

\section{CONCLUSION}

The present work was among the very few studies evaluating of bacteria and fungi contamination in the air inside classroom at Srinakharinwirot University. Moreover, we assessed the hourly and season variations of the air inside classroom. Almost all the classroom at Srinakharinwirot University were heavily contaminated with bacteria and fungi. Thus, attention must be given to control those environmental factors which favor the growth and multiplication of microbes in indoor environment of classroom to safeguard health of users and workers. However, Air conditioner should be maintained regularly, cleaning and disinfected daily.

\section{ACKNOWLEDGEMENT}

The authors are grateful to the faculty of Physical Therapy, Srinakharinwirot University for the financial support. (project number 179/2018) 


\section{REFERENCES}

1. Hayleeyesus SF, Manaye AM. Microbiological quality of indoor air in University Libraries. Asian Pacific J Trop Biomed. 2014; 4: 312-317.

2. Liu MH, Tung TH, Chung FF, Chuang LC, Wan GH. High total volatile organic compounds pollution in a hospital dental department. Environ Monit Assess. 2017; 189: 571-578.

3. Wemedo SA, Ede PN, Chuku A. Interaction Between Building Design and Indoor Airborne Microbial Load in Nigeria. Asian J Biol Sci. 2012; 5: 183-191.

4. Gilbert Y, Veillette M, Duchaine C. Airborne bacteria and antibiotic resistance genes in hospital rooms. Aerobiologia. 2010; 26: 185-194.

5. Huttunen R, Åttman E, Aittoniemi J, Outinen T, Syrjänen J, Kärki T, Lyytikäinen O. Nosocomial bloodstream infections in a Finnish tertiary care hospital: a retrospective cohort study of 2175 episodes during the years 19992001 and 2005-2010. Infect Dis (Lond). 2015; 47: 20-26.

6. Alangaden JG. Nosocomial fungal infections: epidemiology, infection control, and prevention. Infect Dis Clin North Am. 2011; 25: 201-225.

7. Patterson KC, Strek ME. Diagnosis and treatment of pulmonary aspergillosis syndromes. Chest. 2014; 146: 13581368.

8. Vonberg RP, Gastmeier P. Nosocomial aspergillosis in outbreak settings. J Hosp Infect. 2006; 63: 246-54

9. Perdelli F, Sartini M, Spangnolo AM, Dallera M, Lomardi R, Cristina ML. A problem of hospital hygiene: the presence of Aspergilli in hospital wards with different air-conditioning features. Am J Infect Control. 2006; 34: 264-268

10. Kavita N, Jyoti G. Microbial air contamination in a school. Int J Curr Microbiol App Sci 2013; 2: 404-410.

11. Pasquarella C, Pitzurrat O, Savino A. The index of microbial air contamination. J Hosp Infect. 2000; 46: 241-256.

12. Leyral G, Joffin JN. 1998. Technical Microbiology: 2, Technical Documentation. $2^{\text {nd }}$ Edition, CRDP d'Aquitaine, Bordeaux, $304 \mathrm{p}$.

13. Rajash B, Rattan LI. Essential of Medical Microbiology. $4^{\text {th }}$ Edition, Jayppe Brothers Medical Publishers, New Delhi, 2008; 415-451.

14 Department of Occupational Safety and Health, Ministry of Human Resources, Malaysia. Industry Code of Practice on Indoor Air Quality 2010.

15. Stryjakowska-Sekulska M, Piotraszewska-Pajak A, Szyszka A, Nowicki M, Filipiak M.Microbiological quality of indoor air in university rooms. Polish J Enviro Stud. 2007; 16: 623-632.

16. Jakkapong N, Sirilak C, Waralee B. Microbial air contamination in laboratory rooms, faculty of science, Payap University. KKU Sci J. 2014; 42: 341-349.

17. Siriporn S, Ganjana N. Ambient microbial contamination in different hospital scales. KKU Res J. 2012; 12:92-101.

18. Krisaneeya S. Airborne bacteria and fungi in the hospital and the sampling method comparison. Thai J Health Promot Environ. 2005; 29: 113-224. 